\title{
Ortholinea auratae n. sp. (Myxozoa, Ortholineidae) infecting the urinary bladder of the gilthead seabream Sparus aurata (Teleostei, Sparidae), in a Portuguese fish farm
}

\author{
Luis F. Rangel • Sónia Rocha • Muhammad H. Borkhanuddin • \\ Gábor Cech • Ricardo Castro • Graça Casal • Carlos Azevedo • \\ Ricardo Severino • Csaba Székely • Maria J. Santos
}

Received: 20 March 2014 / Accepted: 19 June 2014

(C) Springer-Verlag Berlin Heidelberg 2014

\begin{abstract}
A new myxosporean species, Ortholinea auratae n. sp., is described from the gilthead seabream, Sparus aurata Linnaeus, 1758 (Teleostei, Sparidae) from a fish farm in Algarve, Portugal. Plasmodia and spores were found in the urinary bladder and, less frequently, in the posterior kidney. Plasmodia were polymorphic, presenting an irregular cellular
\end{abstract}

\footnotetext{
L. F. Rangel $(\bowtie) \cdot$ R. Castro $\cdot$ M. J. Santos

Faculty of Sciences, Department of Biology, University of Porto, Rua do Campo Alegre, s/n, Edifício FC4, 4169-007 Porto, Portugal e-mail: luisfiliperangel@sapo.pt

L. F. Rangel $\cdot$ S. Rocha $\cdot$ R. Castro $\cdot$ G. Casal $\cdot$ C. Azevedo $\cdot$ R. Severino $\cdot$ M. J. Santos Interdisciplinary Centre of Marine and Environmental Research (CIIMAR/CIMAR), University of Porto, Rua dos Bragas 289, 4050-123 Porto, Portugal
}

M. H. Borkhanuddin • G. Cech • C. Székely Institute for Veterinary Medical Research, Centre for Agricultural Research, Hungarian Academy of Sciences, Hungária krt. 21, 1143 Budapest, Hungary

G. Casal

Department of Sciences, High Institute of Health Sciences-North (CESPU), Rua Central da Gandra, 1317, 4585-116 Gandra, Portugal

\section{Azevedo}

Laboratory of Cell Biology, Institute of Biomedical Sciences Abel Salazar (ICBAS/UP), University of Porto, Rua Jorge Viterbo Ferreira no. 228, 4050-313 Porto, Portugal

\section{Azevedo}

Zoology Department, College of Sciences, King Saud University, Riyadh 11451, Saudi Arabia

\section{H. Borkhanuddin}

School of Marine Science and Environment, Universiti Malaysia, Kuala Terengganu, Terengganu, Malaysia membrane due to the presence of several peripheral projections, which in turn were covered by a glycocalyx-like sheet. Mature spores were subspherical in valvular view and ellipsoidal in sutural view, measuring $9.0 \pm 0.3(8.2-10.1) \mu \mathrm{m}$ in length, $8.3 \pm 0.4(7.5-9.1) \mu \mathrm{m}$ in width, and $7.2 \pm 0.5(6.3-8.4)$ $\mu \mathrm{m}$ in thickness. The two valves comprising the spores displayed an intricate pattern of surface ridges and were also enveloped by a glycocalyx-like sheet. Two subspherical polar capsules, $3.2 \pm 0.1$ (2.9-3.6) $\mu \mathrm{m}$ long and 2.7 \pm 0.1 (2.4-2.9) $\mu \mathrm{m}$ wide, were located at the anterior pole and displayed divergent orientation. The polar filament coiled in three to four turns. The comprehensive analysis of the parasite's ultrastructural observations and molecular data for the small subunit (SSU) ribosomal DNA (rDNA) gene identify $O$. auratae n. sp. as a new species, clustering together with other myxosporeans infecting the excretory system to form a subclade of the main freshwater clade.

Keywords Myxozoa $\cdot$ Ortholinea auratae n. sp. S Sparus aurata - SSU rDNA · Ultrastructure · Glycocalyx-like sheet . Urinary bladder

\section{Introduction}

The gilthead seabream, Sparus aurata Linnaeus, 1758, is a teleost fish of great economic value in the Mediterranean and Portuguese coasts. Several studies have been conducted on the microorganisms parasitizing this species, mainly in the Mediterranean coast (Fioravanti et al. 2006; Merella et al. 2006; Mladineo et al. 2010); however, in Portugal, only one study from the archipelago of Madeira concerns this subject (Costa et al. 1998). 
Nine myxozoan species have been described infecting the gilthead seabream: Zschokkella auratis (Rocha et al. 2013), Ceratomyxa sparusaurati (Sitjà-Bobadilla et al. 1995), Ceratomyxa sp. 1 ex $S$. aurata and Ceratomyxa sp. 2 ex S. aurata (Alama-Bermejo et al. 2011), all from the gallbladder; Sphaerospora sparidarum (Sitjà-Bobadilla and ÁlvarezPellitero 2001), and Sphaerospora sparis (Sitjà-Bobadilla et al. 1992; Sitjà-Bobadilla and Álvarez-Pellitero 1995; Bartošová et al. 2013) from the kidney; Enteromyxum leei (Diamant et al. 1994) from the intestinal tract; Henneguya sp. (Bahri et al. 1996) from the gills and heart; and Kudoa iwatai (Diamant et al. 2005), which is a systemic species. Resulting from a parasitological survey conducted in sparid fishes from a southern Portuguese fish farm, a new species belonging to the genus Ortholinea Shulman, 1962 was detected infecting the urinary bladder of $S$. aurata. This constitutes the first record of a myxosporean parasite described from this organ in the gilthead seabream as well as the first reference of an Ortholinea species from the Portuguese coast.

The genus Ortholinea includes about 20 species, mostly coelozoic in the excretory system, with the exception of four species: Ortholinea visakhapatnamensis, which infects the visceral peritoneum (Padma Dorothy and Kalavati 1993); Ortholinea percotti, which infects the gills and fins (Akhmerov 1960); and Ortholinea asymmetrica and Ortholinea australis, which infect the gallbladder (Lom et al. 1992; Kovalyova et al. 1993). Ortholinea species usually infect marine fishes; only Ortholinea africanus is known to parasitize a freshwater host, the Nile tilapia Oreochromis niloticus (Abdel-Ghaffar et al. 2008). Spores are described as spherical or subspherical, slightly flattened parallel to the sutural plane or pointed posteriorly, and containing two subspherical to pyriform polar capsules and a binucleate sporoplasm (Lom and Dyková 2006), revealing the lack of precise characteristics for morphological differentiation. In fact, phylogenetic studies have shown that spore morphology constitutes a somewhat artificial criterion for the discernment of true myxosporean taxonomy, further revealing aquatic environment, tissue tropism, and host phylogenetic proximity as more reliable criteria for acknowledging the phylogenetic and evolutionary issues of Myxosporea (Kent et al. 2001; Eszterbauer 2004; Holzer et al. 2004; Fiala 2006; Bartošová et al. 2009; Fiala and Bartošová 2010; Carriero et al. 2013; Rocha et al. 2013). However, in the case of Ortholinea, GenBank provides sequences for the small subunit (SSU) ribosomal DNA (rDNA) of only three species, hindering the molecular analysis of this genus and giving new need to morphological comparison. The present study seeks to address this gap in the knowledge by providing a morphological, ultrastructural, and molecular description of the Ortholinea species found infecting the urinary bladder of S. aurata.

\section{Material and methods}

Between June 2012 and May 2013, 124 specimens of $S$. aurata were collected from a fish farm facility located at the Alvor estuary, Atlantic coast $\left(37^{\circ} 8^{\prime} \mathrm{N}, 8^{\circ} 37^{\prime} \mathrm{W}\right)$, Portimão, Algarve, Portugal.

The fish were kept fresh on ice and transported to the laboratory, where dissection was performed and followed by the parasitological survey of various internal tissues and organs. The gills, fins, and eyes were also examined.

Infected samples were examined and photographed using a Zeiss Axiophot microscope (Grupo Taper, Sintra, Portugal), equipped with a Zeiss AxioCam Icc3 digital camera. AxioVision 4.6 software (Grupo Taper) was used for the image analysis. Spore's morphometry was determined from fresh material, in accordance to Lom and Arthur (1989). All measurements include the mean value \pm standard deviations (SDs), range of variation, and number of spores measured (range, $n$ ).

Infected samples of urine and urinary bladder tissue were collected and prepared for electron microscopy and molecular procedures.

For transmission electron microscopy, small fragments of the urinary bladder containing plasmodia and spores were fixed in $5 \%$ glutaraldehyde buffered in $0.2 \mathrm{M}$ sodium cacodylate (pH 7.4) for $24 \mathrm{~h}$ at $4{ }^{\circ} \mathrm{C}$, washed overnight in the same buffer, and then postfixed in $2 \%$ osmium tetroxide with the same buffer for $4 \mathrm{~h}$. After dehydration in an ascending ethanol series ending in propylene oxide, the samples were embedded in EPON. Semi-thin sections were stained with methylene blueazure II. Ultrathin sections were double contrasted with uranyl acetate and lead citrate and were observed and photographed using a JEOL 100CXII TEM operated at $60 \mathrm{kV}$.

For scanning electron microscopy, free spores were isolated from infected urine and fixed in $5 \%$ glutaraldehyde buffered in $0.2 \mathrm{M}$ sodium cacodylate $(\mathrm{pH} 7.4)$ for $20 \mathrm{~h}$ at $4{ }^{\circ} \mathrm{C}$, washed in the same buffer at the same temperature, and postfixed in $2 \%$ osmium tetroxide with the same buffer for $3 \mathrm{~h}$. The samples were then dehydrated in an ascending ethanol series, critical point dried, coated with a goldpalladium alloy (60\%), and observed and photographed in a JSM-6301 F SEM operated at $15 \mathrm{kV}$.

For the molecular analysis, DNA was extracted from spores preserved in ethanol using a DNeasy ${ }^{\mathrm{TM}}$ tissue kit (animal tissue protocol; Qiagen, Germany) according to the manufacturer's instructions. For the amplification of the SSU rDNA, nested PCR was performed. For the first PCR, a set of universal eukaryotic primers was used (Table 1). The total volume of the PCR reaction was $25 \mu \mathrm{l}$ and comprised $2 \mu \mathrm{l}$ of genomic DNA, $5 \mu \mathrm{l}$ of $1 \mathrm{mM}$ deoxynucleotides (dNTPs) (MBI Fermentas), $0.25 \mu \mathrm{l}$ of each primer, $2.5 \mu \mathrm{l}$ of $10 \times \mathrm{Taq}$ buffer (MBI Fermentas), $0.1 \mu \mathrm{l}$ of Taq polymerase ( $2 \mathrm{U}$; MBI Fermentas), and $15 \mu \mathrm{l}$ of water. The following profile was used to amplify the 
Table 1 Primers used for PCR and sequencing

\begin{tabular}{llll}
\hline Primer & Sequence & Application & Source \\
\hline ERIB1 & 5'-ACC TGG TTG ATC CTG CCA G-3' & 1st round PCR & Barta et al. (1997) \\
ERIB10 & 5'-CTT CCG CAG GTT CAC CTA CGG-3' & 1st round PCR & Barta et al. (1997) \\
Myx1F & 5'-GTG AGA CTG CGG ACG GCT CAG-3' & 2nd round PCR & Hallett and Diamant (2001) \\
SphR & 5'-GTT ACC ATT GTA GCG CGC GT-3' & 2nd round PCR and sequencing & Eszterbauer and Székely (2004) \\
MC5 & 5'-CCT GAG AAA CGG CTA CCA CAT CCA-3' & Sequencing & Molnár et al. (2002) \\
MB5r & 5'-ACC GCT CCT GTT AAT CAT CAC C-3' & Sequencing & Eszterbauer (2004) \\
MB5f & 5'-GAT GAT TAA CAG GAG CGG TTG G-3' & Sequencing & Eszterbauer (2004) \\
ACT1fr & 5'-TTG GGT AAT TTG CGC GCC TGC TGC C -3' & Sequencing & Hallett and Diamant (2001) \\
\hline
\end{tabular}

SSU rDNA region: an initial denaturation step at $95{ }^{\circ} \mathrm{C}$ for $3 \mathrm{~min}$; 35 cycles at $95{ }^{\circ} \mathrm{C}$ for $1 \mathrm{~min}, 55^{\circ} \mathrm{C}$ for $1 \mathrm{~min}$, and $72{ }^{\circ} \mathrm{C}$ for $2 \mathrm{~min}$; and termination with an extension period of $72{ }^{\circ} \mathrm{C}$ for $7 \mathrm{~min}$, before storage at $4{ }^{\circ} \mathrm{C}$.

Second PCR was performed using myxosporean-specific primers (Table 1). PCRs were conducted with a volume of $50 \mu \mathrm{l}$ consisting of $1 \mu \mathrm{l}$ of amplified DNA, $10 \mu \mathrm{l}$ of $1 \mathrm{mM}$ dNTPs (MBI Fermentas), $0.5 \mu$ l of each primer, $5 \mu$ of $10 \times$ Taq buffer (MBI Fermentas), $0.2 \mu \mathrm{l}$ of Taq polymerase (2 U; MBI Fermentas), and $33 \mu$ of water. Amplification was carried out using the following profile: $95{ }^{\circ} \mathrm{C}$ for $3 \mathrm{~min}$; 35 cycles at $95{ }^{\circ} \mathrm{C}$ for $50 \mathrm{~s}, 50{ }^{\circ} \mathrm{C}$ for $50 \mathrm{~s}$, and $72{ }^{\circ} \mathrm{C}$ for $1 \mathrm{~min} 40 \mathrm{~s}$; and termination with an extension period of $72^{\circ} \mathrm{C}$ for $7 \mathrm{~min}$, before storage at $4{ }^{\circ} \mathrm{C}$.

PCR cycles were run in a PTC-200 thermocycler (MJ Research). The PCR products were electrophoresed through a $1 \%$ agarose $1 \times$ Tris-acetate-EDTA (TAE) buffer gel stained with $1 \%$ ethidium bromide. Amplified DNA was purified using the EZ-10 Spin Column PCR Purification Kit (Bio Basic Inc.). Purified PCR products were sequenced with the primers listed in Table 1, using the ABI BigDye Terminator v3.1 Cycle Sequencing Kit with an ABI 3100 Genetic Analyzer.

Phylogenetic analysis was performed using the obtained SSU rDNA sequence of the isolate and other myxosporean SSU rDNA sequences retrieved from GenBank, namely, those presenting the highest similarity score in Basic Local Alignment Search Tool (BLAST). Also included in the analysis were all Ortholinea SSU rDNA sequences available in GenBank as well as the SSU rDNA sequences of the other myxosporean species that have been described from the gilthead seabream and other representative species of myxosporean phylogeny. Tetracapsuloides bryosalmonae and Buddenbrockia plumatellae were selected as out-group species.

To ensure the accuracy of the analysis and to maintain a high tree resolution, sequences with less than 1,000 bp were not used, avoiding loss of information due to shortening of the aligned sequences and the appearance of numerous gaps (Liu et al. 2010). Alignments were performed with ClustalW in MEGA 5.05 software (Tamura et al. 2011), with an opening gap penalty of 10 and a gap extension of 4 for both paired and multiple alignments, resulting in a total of 2,481-bp informative characters in the final dataset. Subsequent phylogenetic and molecular evolutionary analyses were conducted using MEGA 5.05, using maximum parsimony (MP), neighborjoining (NJ), and maximum likelihood (ML) methodologies. For MP, the close neighbor-interchange heuristic option with a search factor of 1 and random initial tree addition of 500 replicates was performed. For NJ, a Kimura two-parameter substitution model with gamma distribution (shape parameter=1.4) was performed. For ML, the general time-reversible substitution model with four gamma-distributed rate variations among sites was performed. All positions with less than $95 \%$ site coverage were eliminated from all trees, resulting in a total of 896 positions in the final dataset. The bootstrap consensus tree was inferred from 100 replicates for MP and 500 replicates for NJ and ML.

The second alignment was performed for the SSU rDNA sequence of the case isolate and the SSU rDNA sequences presenting the highest similarity score in BLAST (clustering in the same clade of the case isolate), resulting in a total of 2,129-bp positions in the final dataset. Distance estimation was carried out in MEGA 5.05, using the Kimura twoparameter model distance matrix for transitions and transversions, with all ambiguous positions removed for each sequence pair.

\section{Results}

The examination of $S$. aurata specimens revealed the presence of a coelozoic myxosporean parasite in the urinary bladder (Fig. 1). Plasmodia and mature spores were observed floating free in the urine and, in more intense infections, covering the inner wall of the urinary bladder (Fig. 1a). Infection was also found in the terminal portion of the posterior kidney. Prevalence of infection was determined at 51.6\% (64 infected in 124 examined specimens). No symptoms or macroscopic signs of infection were observed. 

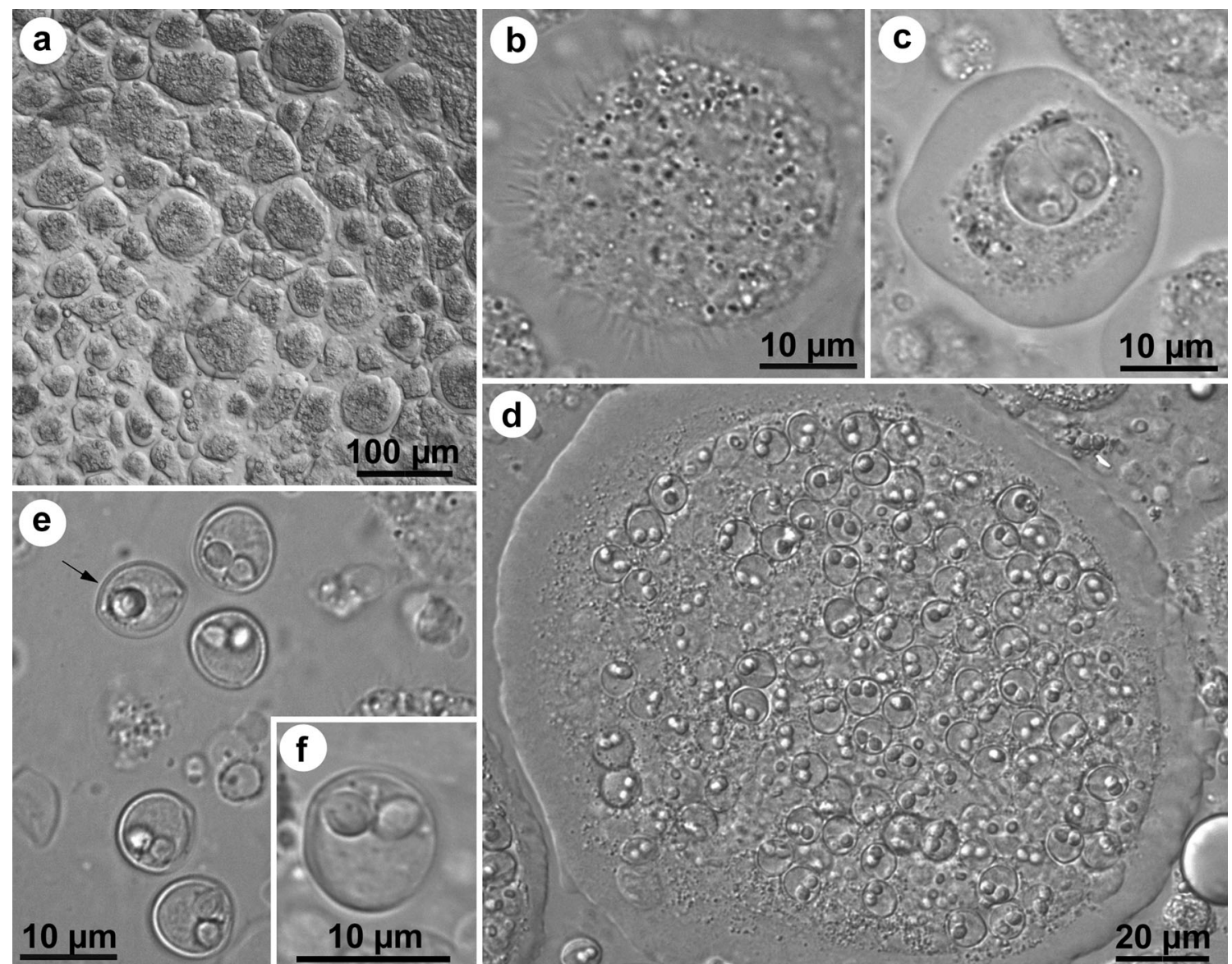

Fig. 1 Plasmodia and spores of Ortholinea auratae n. sp. from the urinary bladder of Sparus aurata as observed using the differential interference contrast optics. a Cluster of plasmodia. b Young plasmodium displaying a highly irregular cellular membrane, due to the presence of numerous peripheral projections. c Mature disporic plasmodium containing a disporic pansporoblast. d Mature polysporic plasmodium containing many developing spores. e Mature spores in valvular view and one in sutural view (arrow). f Mature spore in valvular view, displaying a visible intercapsular process

\section{Morphologic description}

Plasmodia were polymorphic, the most common shape being rounded (Fig. 1a-d), and displayed an irregular cellular membrane due to the presence of several long and thin peripheral projections (Figs. $1 \mathrm{~b}$ and $2 \mathrm{a}-\mathrm{c}$ ), which appeared covering the entire surface of these structures or projecting from only a portion of the plasmodial membrane. A glycocalyx-like sheet enveloped the entire surface of the plasmodia, including the peripheral projections (Figs. 2b, c and 3e). The ectoplasmic margin was transparent and void of organelles, while the endoplasm was denser and granular, presenting several vegetative nuclei, vesicles, and numerous mitochondria (Figs. 1c, d and 2b, c). Plasmodia were polysporous (Fig. 1d) and, less frequently, disporous (Fig. 1c). Plasmodia containing the earliest stages of sporogenic development ranged between 15.0-42.9 × 14.2-34.4 $\mu \mathrm{m}$ $(n=30)$, while mature plasmodia, containing developing sporoblasts and immature spores (Fig. $3 \mathrm{a}-\mathrm{c}$ ), ranged between $24.3-55.4 \times 22.1-39.6 \mu \mathrm{m}(n=10)$.
Mature spores were subspherical in valvular view (Fig. 1e, f) and ellipsoidal in sutural view (Fig. 1e), measuring $9.0 \pm 0.3 \mu \mathrm{m}(8.2-10.1 ; n=62)$ in length, $8.3 \pm 0.4 \mu \mathrm{m}$ (7.5-9.1; $n=42)$ in width, and $7.2 \pm 0.5 \mu \mathrm{m}(6.3-8.4 ; n=26)$ in thickness. The two valves comprising the spore's wall were united along a straight and evident suture line and presented an intricate pattern of surface ridges (Fig. 4a, b), with few variations between spores. Each valve displayed a minimum of 19 ridges. The sutural ridge was visible and flanked on each side by three to four parallel circular extrasutural ridges. At the center of the valves, the ridges coiled concentrically (Fig. 4b) or instead formed a set of extrasutural central ridges running longitudinally and/or diagonally (Fig. 4a). Similar to the plasmodia cellular membrane, the spore's wall also appeared enveloped by a glycocalyx-like sheet (Fig. 3d, e).

Spores contained two equal subspherical polar capsules, $3.2 \pm 0.1 \mu \mathrm{m}$ long $(2.9-3.6 ; n=60)$ and $2.7 \pm 0.1 \mu \mathrm{m}$ wide $(2.4-2.9 ; n=64)$, presenting divergent orientation and opening to opposite sides of the suture line. A conspicuous intercapsular process was observed (Fig. 1e, f). The polar 


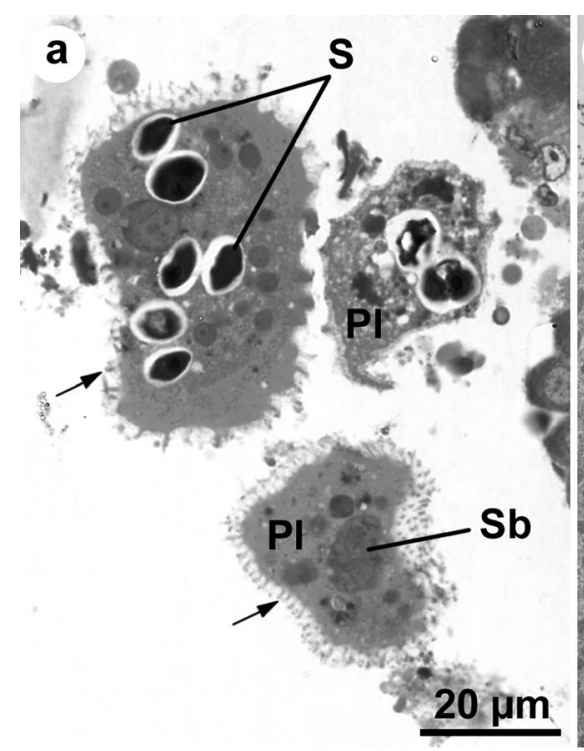

Fig. 2 Light and transmission electron micrographs of Ortholinea auratae n. sp. from the urinary bladder of Sparus auratus. a Semi-thin section of plasmodia $(\mathrm{Pl})$ containing different sporogenic stages of development and displaying highly irregular cellular membranes (arrows). Notice the sporoblast $(S b)$ contained within an immature plasmodium as well as the developing spores $(S)$ within more mature plasmodia. (b) Ultrathin section of a young plasmodium $(P l)$ displaying vegetative

capsules displayed a double-layered wall, comprised of a thin outer electron-dense layer and a larger inner electron-lucent layer surrounding a dense and slightly heterogenous matrix (Fig. 3c, f). The polar filament coiled in three to four turns and, when extruded, measured $23.6 \pm 1.1 \mu \mathrm{m}(22.2-25.1 ; n=6)$ in length. The sporoplasm was binucleated, contained several electrondense sporoplasmossomes, and lacked an iodinophilous vacuole (Fig. 3c).

The ultrastructural features here described are represented in a schematic drawing (Fig. 5), providing better perception of the spore's morphology.

\section{Taxonomic summary}

Parasite species: Ortholinea auratae n. sp. (Ortholineidae). Type host: S. aurata Linnaeus, 1758 (Teleostei, Sparidae).

Site of infection: Urinary bladder and terminal portion of the posterior kidney.

Type locality: Alvor estuary, Atlantic coast $\left(37^{\circ} 08^{\prime} \mathrm{N}, 8^{\circ}\right.$ $37^{\prime} \mathrm{W}$ ), Portimão, Algarve, Portugal.

Prevalence: Rate of $51.6 \%$ (64 out of 124).

Pathology: No symptoms or macroscopic signs of infection were evident.

Etymology: The specific epithet auratae refers to the piscine host $S$. aurata.
Materials deposited: Slides containing semi-thin sections of mature plasmodia and spores were deposited in our institution collection CIIMAR, PT, reference: CIIMAR 2013.2

\section{Phylogenetic analyses}

The resulting sequences for the SSU rDNA gene, obtained from plasmodia and spores collected from three infected fish specimens, were sequenced and deposited in GenBank under the accession numbers KF703856, KF703857, and KF703858. The three sequences obtained were identical and based on 1,546, 1,660, and 1,689 bp, respectively. Pairwise distances among the SSU rDNA sequences showed the highest similarity to Acauda hoffmani (89.7 \%), Myxobilatus gasterostei (85.8\%), Hoferellus gilsoni (79.3\%), Zschokkella sp. AH2003 (77.7 \%), and Ortholinea orientalis (79.9\%).

$\mathrm{MP} / \mathrm{NJ} / \mathrm{ML}$ analyses of the SSU rDNA sequences placed the parasite within the excretory system clade of the major freshwater clade, alongside the sequences of $A$. hoffmani, H. gilsoni, M. gasterostei, Zschokkella sp. AH2003, and $O$. orientalis, with a bootstrap support value of $67 \%$ for MP, $84 \%$ for NJ, and $55 \%$ for ML (Fig. 6). These five myxosporean species infect the kidney, urinary bladder, and ureters of freshwater fish, with the exception of $O$. orientalis, which infects the ureters of two marine fish hosts, Clupea harengus Linnaeus, 1758 and Sprattus sprattus Linnaeus, 

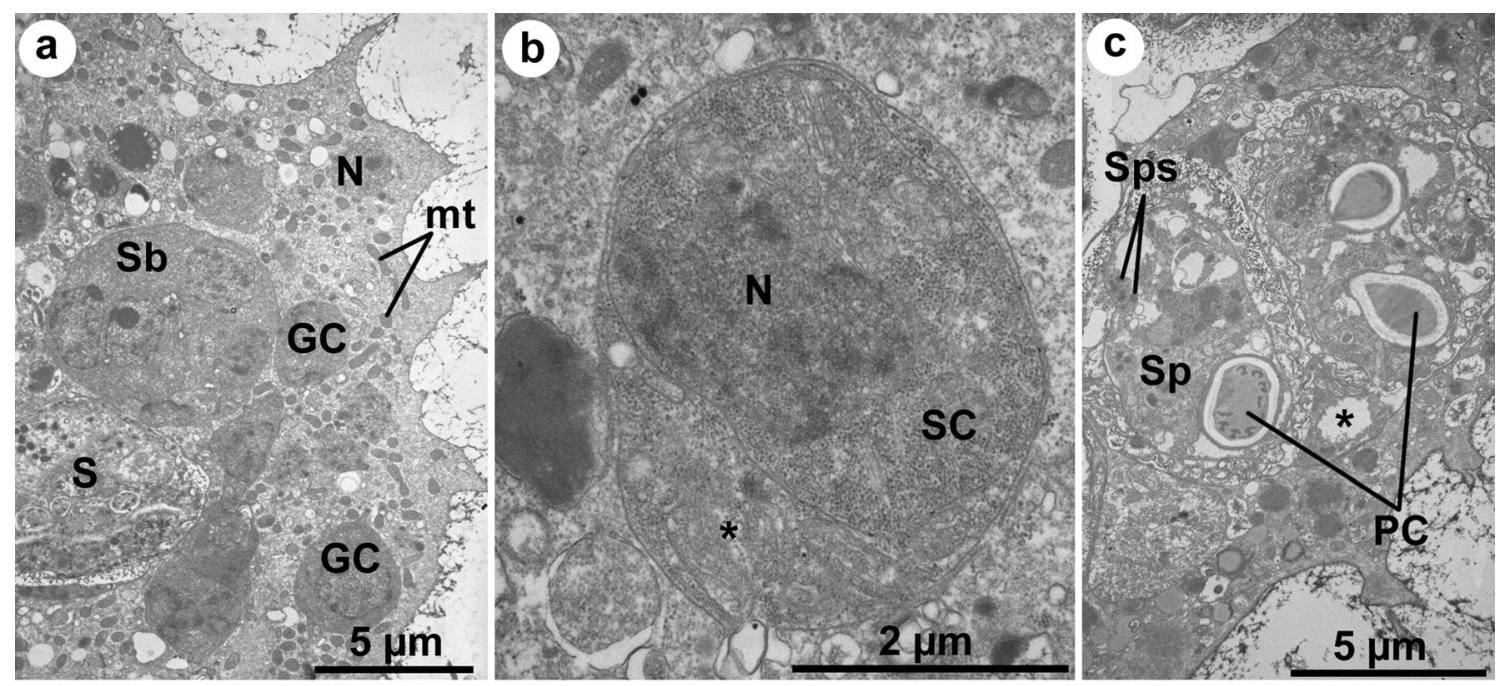
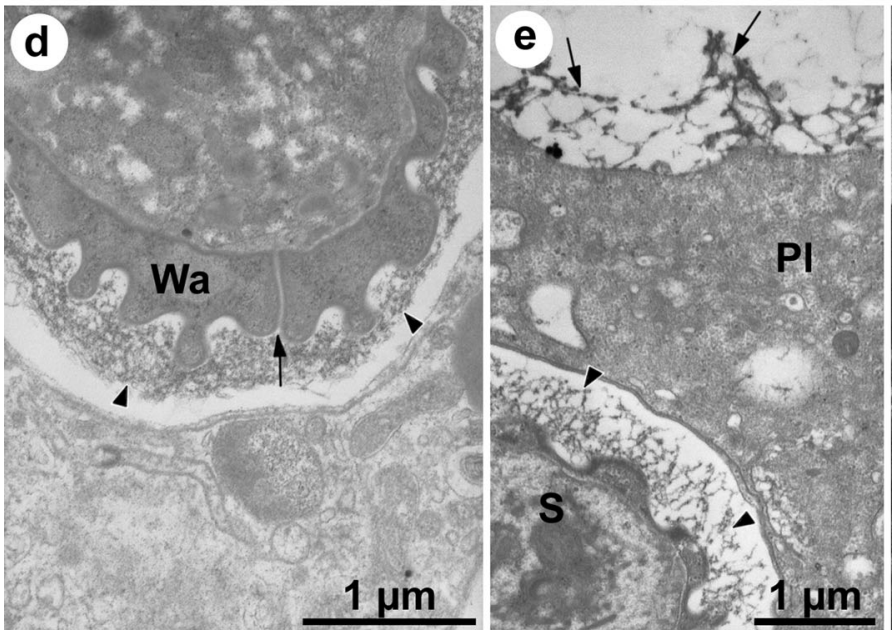



longitudinal and transverse section as well as the sporoplasm $(S p)$ containing several sporoplasmossomes (Sps). d The spore's wall $(\mathrm{Wa})$ was comprised by two shell valves uniting along a straight suture line (arrow) and enveloped in a glycocalyx-like sheet (arrowheads). e Detailed aspect of the glycocalyx-like sheet (arrowheads) enveloping the spore $(S)$ wall. Notice the cellular membrane of the plasmodium $(P l)$ also covered by a glycocalyx-like sheet (arrows). f Transverse section of a polar capsule, displaying its double-layer wall (arrowheads) containing a heterogeneous matrix (asterisk) and an electron-dense polar filament $(P F)$

leydigi and Chloromyxum clavatum. The marine excretory system clade is represented by members of Zschokkella, Sphaerospora, and one Sinuolinea species; the marine histozoic clade is represented by Enteromyxum and the marine coelozoic clade by Ceratomyxa, Zschokkella, and Ellipsomyxa.

\section{Discussion}

In acknowledging the difficulties inherent to the differentiation of genera belonging to the family Ortholineidae (Lom and Noble 1984; Lom and Dyková 2006), the present study uses 


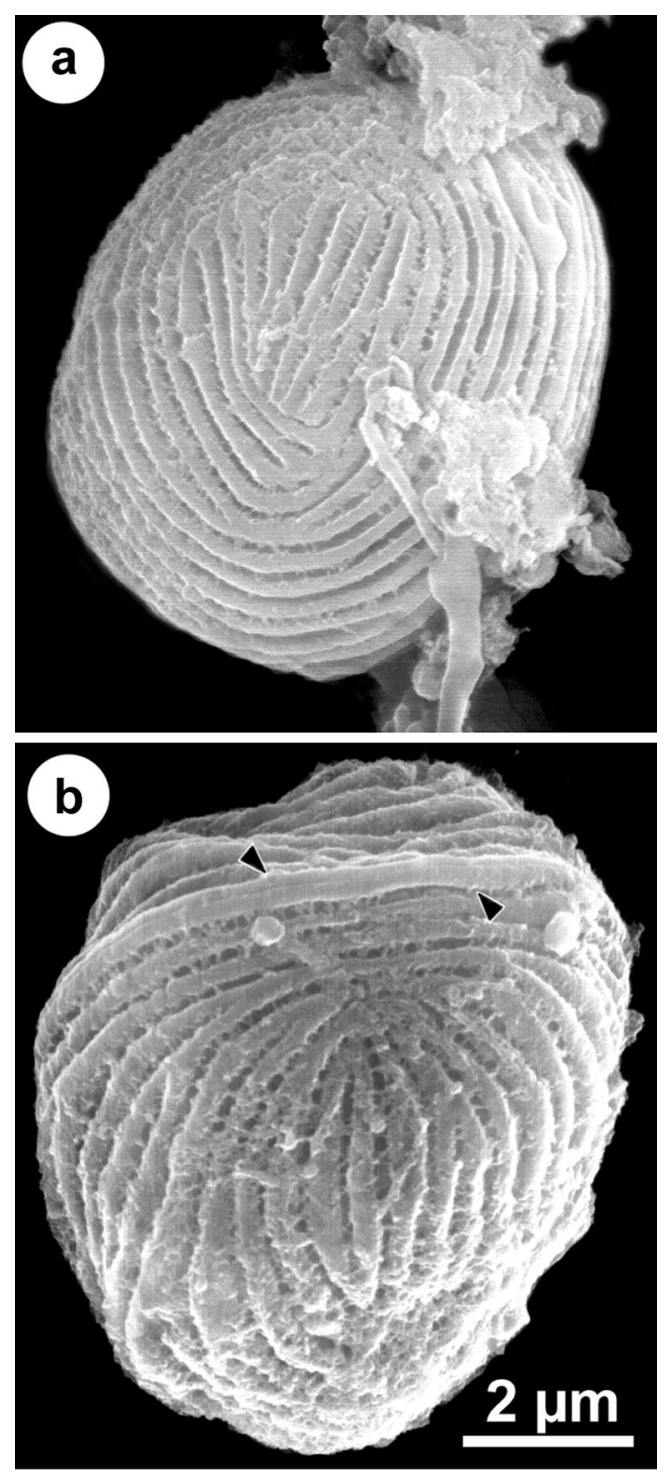

Fig. 4 Scanning electron micrographs of Ortholinea auratae n. sp. from the urinary bladder of Sparus auratus. a Spore in frontal valvular view, allowing recognition of the surface pattern formed by the ridges. $\mathbf{b}$ Spore in slightly oblique sutural view, evidencing the suture line (arrowheads) and the organization of the surface ridges

combined morphological, ultrastructural, and molecular features to describe the myxosporean parasite infecting the urinary bladder of $S$. aurata.

Considering that the gilthead seabream inhabits both brackish and marine habitats and that molecular studies suggest tissue tropism as a phylogenetic trend for myxosporeans (Eszterbauer 2004; Holzer et al. 2004; Fiala 2006; Freeman et al. 2008; Bartošová et al. 2011), only the records of Ortholinea from the excretory system, both freshwater and marine, were considered for morphological comparison. Also, several studies report surface ridges as a reliable feature for morphological differentiation (Lom and Dyková 1993, 2006; Bartošová and Fiala 2011), including for members of Ortholinea (Ali 2000, 2009); therefore, species with smooth

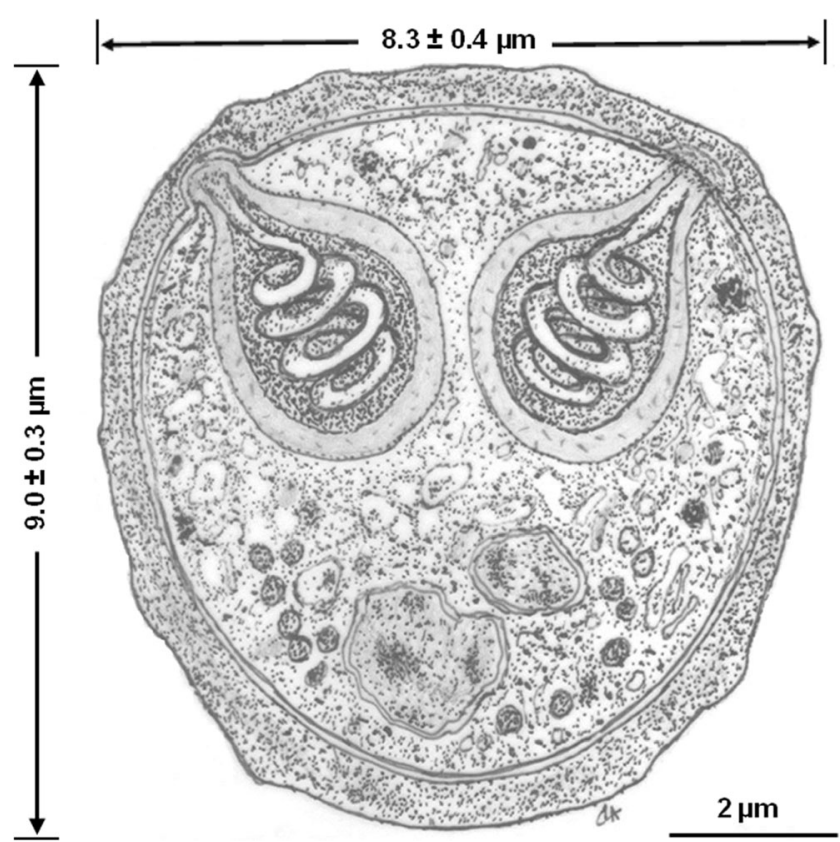

Fig. 5 Schematic drawing of the spore of Ortholinea auratae n. sp.

valves were not compared. Among the 20 known Ortholinea species, there are only five species with similar spore dimensions that infect the excretory system and have surface ridges, differing from $O$. auratae n. sp. in several aspects of the morphometry (Table 2) as well as in the ultrastructural detail of the surface ridges, polar capsules, and suture line. For instance, Ortholinea macruri and Ortholinea striateculus present pyriform polar capsules; Ortholinea undulans also presents pyriform polar capsules, as well as an undulating suture line; and Ortholinea fluviatilis displays a slightly undulating suture line (Meglitsch 1970; Kovalyova et al. 1993; Su and White 1994; Lom and Dyková 1995).

Turning to consider the ultrastructure of the sporogenic development, $O$. auratae n. sp. displays pansporoblast formation, thus following what it seems to be the tendency for Ortholinea species, despite the few studies concerning this subject (Padma Dorothy and Kalavati 1993; Lom and Dyková 1995; Sarkar 1999; Ali 2000; Moshu and Trombitsky 2006). Only $O$. asymmetrica is known to form spores directly from the generative cells (Kovalyova et al. 1993). The plasmodial development of $O$. auratae n. sp. is similar to those usually recognized in coelozoic myxosporeans, since it is characterized by variations in size and the differentiation of peripheral projections, supposedly for the improvement of nutritional intake (Sitjà-Bobadilla and Álvarez-Pellitero 1993, 2001; Rocha et al. 2011). On the other hand, the glycocalyx-like sheet covering the plasmodia, as well as the spores, constitutes a rather distinctive feature, which purpose remains unknown, but may be involved in cellular strengthening towards the host immune response as well as the physical and biological conditions of the organ of infection (Rocha et al. 2013). 


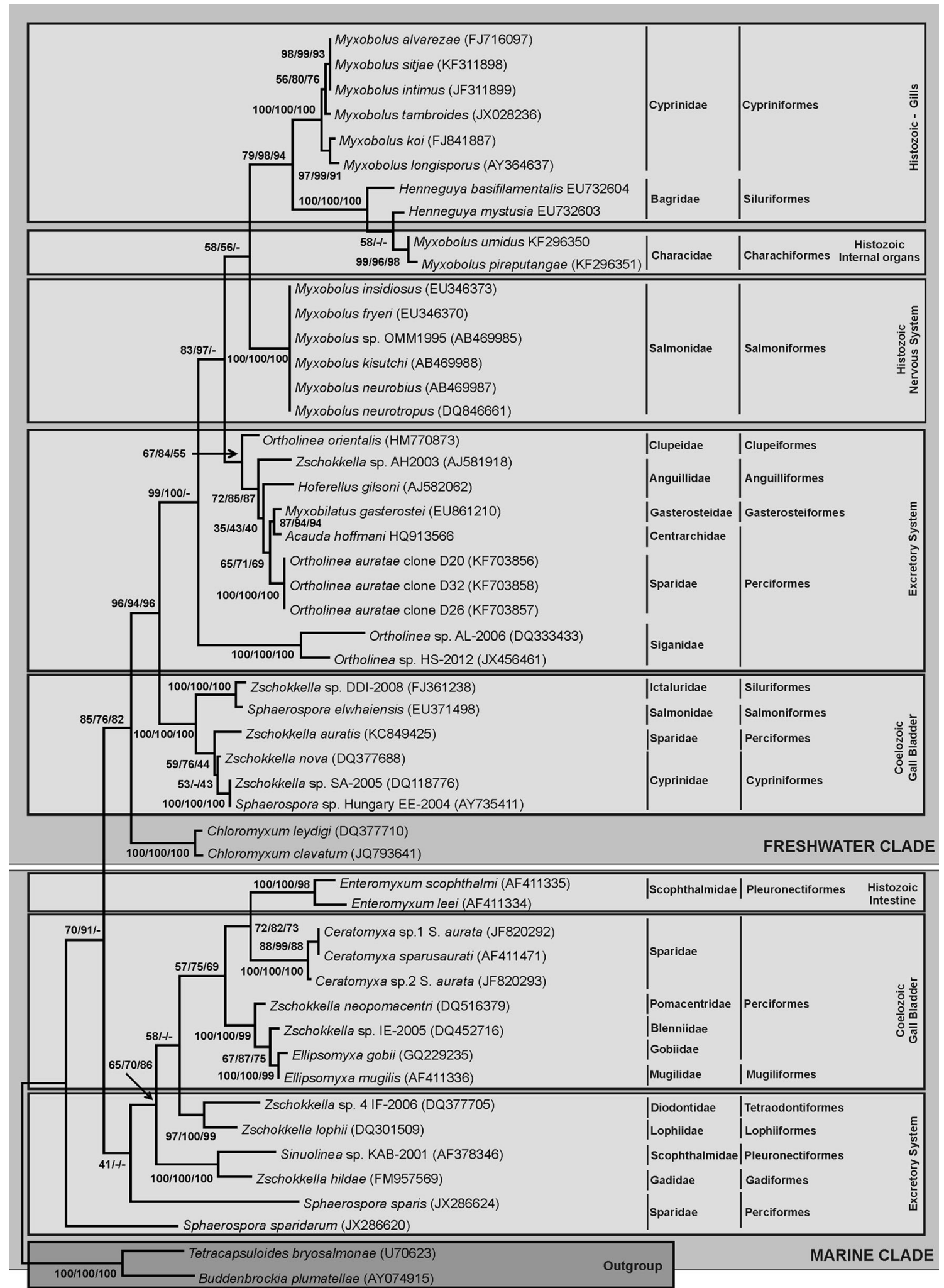

$\longmapsto_{10}$

Fig. 6 Maximum parsimony tree of the SSU rDNA sequence of Ortholinea auratae n. sp. and other selected myxozoan species. The numbers on the branches are bootstrap confidence levels on 100 replicates for MP and 500 replicates for $\mathrm{NJ} / \mathrm{ML}$ trees. There were a total of 896 positions in the final dataset. GenBank accession numbers are in parentheses after the species name; scale is given under the tree 
Molecular comparison between members of the genus Ortholinea is hampered by the scarcity of data available in GenBank, which provides sequences for the SSU rDNA of only three Ortholinea species. O. auratae n. sp. showing higher phylogenetic similarity to species of other genera, rather than to the few of its own genus, not only reveals the pronounced lack of data but also demonstrates the significant influence of other phylogenetic criteria compared to the morphologic criterion.

Concerning the molecular based division of myxosporean into the major freshwater and marine clades (Kent et al. 2001; Fiala 2006; Bartošová et al. 2009), the Ortholinea species here analyzed, including $O$. auratae n. sp., constitute exceptions for this main division. It is not a novelty for marine species to cluster within the major freshwater clade, as it occurs for several species of the genera Henneguya, Chloromyxum, Ceratomyxa, Myxobolus, Myxidium, Parvicapsula, and Sphaeromyxa (Fiala 2006; Azevedo et al. 2009; Rocha et al. 2013) as well as for freshwater species to cluster within the major marine clade, as is the case of Ceratomyxa shasta (Kent et al. 2001; Fiala 2006; Fiala and Bartošová 2010). There are several possible explanations for these exceptions, the main being the migratory pattern of the fish host (namely, for parasites infecting anadromous fishes) (Kent et al. 2001; Fiala 2006) and the myxosporean evolution between aquatic environments as inferred with basis on morphologic characters combined with molecular data (Fiala and Bartošová 2010; Bartošová et al. 2011).

Tissue tropism also constitutes a criterion influencing myxosporean phylogeny (Eszterbauer 2004; Holzer et al. 2004; Fiala 2006; Freeman et al. 2008; Bartošová et al. 2011; Dyková et al. 2013) and is followed by O. auratae n. sp., which clusters together with other species that infect the excretory system. In fact, the analysis here presented supports this phylogenetic trend throughout, excepting only two species, Sphaerospora elwhaiensis and Sphaerospora sp. Hungary EE-2004, which infect the kidney of their hosts (Eszterbauer and Székely 2004; Jones et al. 2011), but cluster within the freshwater coelozoic clade.

More recently, molecular studies have further renewed the contention that host phylogenetic proximity also influences species clustering, therefore playing an important role in myxosporean phylogeny (Carriero et al. 2013; Moreira et al. 2013). The molecular analysis here performed concurs with species clustering by host family and order, especially in the clades containing Henneguya and Myxobolus species, probably because these two genera possess more adequate comparative molecular data. In the case of Ortholinea, the few molecular data available are insufficient to provide information on this evolutionary signal. Although Ortholinea sp. AL-2006 and Ortholinea sp. HS-2012 cluster together, having both been described from a fish host of the family Siganidae, these species are, in fact, parasites of the same host species, 
S. rivulatus, making illations at the family level void of significance. Overall, the paucity of reliable molecular data for most myxosporean genera cannot be ignored when substantiating hypotheses, especially for poorly studied genera such as Ortholinea, for which the acquisition of additional data is crucial.

Acknowledgments This work was financially supported by FCT (Portugal), within the scope of the project DIRDAMyx, reference FCOMP-01-0124-FEDER-020726/FCT-PTDC/MAR/116838/2010 and the Ph.D. fellowship grant SFRH/BD/82237/2011 to L. Rangel; the Eng. António de Almeida Foundation (Portugal); and partially by the grants of the Hungarian Government, managed by the National Development Agency and financed by the Research and Technology Innovation Fund (KTIA AIK-12-1-2013-0017) and OTKA K 100132. This work complies with the current laws of the country where it was performed.

\section{References}

Abdel-Ghaffar F, El-Toukhy A, Al-Quraishy S, Al-Rasheid K, AbdelBaki A, Hegazy A, Bashtar A-R (2008) Five new myxosporean species (Myxozoa: Myxosporea) infecting the Nile tilapia Oreochromis niloticus in Bahr Shebin, Nile Tributary, Nile Delta, Egypt. Parasitol Res 103:1197-1205. doi:10.1007/s00436-0081116-Z

Akhmerov AK (1960) Myxosporidia of fishes of the Amur River basin. Ryb Khoz Vnutr Vodoemov Latv SSR 5:239-308 (In Russian)

Alama-Bermejo G, Raga JA, Holzer AS (2011) Host-parasite relationship of Ceratomyxa puntazzi n. sp. (Myxozoa: Myxosporea) and sharpsnout seabream Diplodus puntazzo (Walbaum, 1792) from the Mediterranean with first data on ceratomyxid host specificity in sparids. Vet Parasitol 182:181-192. doi:10. 1016/j.vetpar.2011.05.012

Ali MA (2000) Ortholinea basma n. sp. (Myxozoa: Myxosporea) from agile klipfish Clinus agilis (Teleostei: Clinidae), light and scanning electron microscopy. Eur J Protistol 36:100-102. doi:10.1016/ S0932-4739(00)80026-7

Ali MA (2009) Light and scanning electron microscopy (SEM) of Ortholinea africanus Abdel-Ghaffar et al., 2008 (Myxozoa: Myxosporea) infecting tilapia fish Oreochromis niloticus (Osteichthyes: Cichlidae) with description of preparation of coelozoic Myxosporea for SEM. Acta Protozool 48:185-190

Azevedo C, Casal G, Garcia P, Matos P, Teles-Grilo L, Matos E (2009) Ultrastructural and phylogenetic data of Chloromyxum riorajum sp. nov. (Myxozoa), a parasite of the stingray Rioraja agassizii in Southern Brazil. Dis Aquat Org 85:41-51. doi:10.3354/dao02067

Bahri S, Hassine OKB, Marques A (1996) Henneguya sp. (Myxosporea, Bivalvulida) infecting the gills of wild gilthead sea bream Sparus aurata L., from the coast of Tunisia. Bull Eur Assoc Fish Pathol 16: $51-53$

Barta JR, Martin DS, Libetator PA, Dashkevicz M, Anderson JW, Feighner SD, Elbrecht A, Perkins-Barrow A, Jenkins MC, Danforth HD, Ruff MD, Profous-Juchelka H (1997) Phylogenetic relationships among eight Eimeria species infecting domestic fowl inferred using complete small subunit ribosomal DNA sequences. J Parasitol 83:262-271

Bartošová P, Fiala I (2011) Molecular evidence for the existence of cryptic species assemblages of several myxosporeans (Myxozoa). Parasitol Res 108:573-583. doi:10.1007/s00436-010-2100-y

Bartošová P, Fiala I, Hypša V (2009) Concatenated SSU and LSU rDNA data confirm the main evolutionary trends within myxosporeans
(Myxozoa: Myxosporea) and provide an effective tool for their molecular phylogenetics. Mol Phylogenet Evol 53:81-93. doi:10. 1016/j.ympev.2009.05.018

Bartošová P, Freeman MA, Yokoyama H, Caffara M, Fiala I (2011) Phylogenetic position of Sphaerospora testicularis and Latyspora scomberomori $\mathrm{n}$. gen. $\mathrm{n}$. sp. (Myxozoa) within the marine urinary clade. Parasitology 138:381-393. doi:10.1017/S0031182010001381

Bartošová P, Fiala I, Jirků M, Cinková M, Caffara M, Fioravanti ML, Atkinson SD, Bartholomew JL, Holzer AS (2013) Sphaerospora sensu stricto: taxonomy, diversity, and evolution of a unique lineage of myxosporeans (Myxozoa). Mol Phylogenet Evol 68:93-105

Carriero MM, Adriano EA, Silva MRM, Ceccarelli PS, Maia AAM (2013) Molecular phylogeny of the Myxobolus and Henneguya genera with several new South American species. PLoS One 8(9): e73713. doi:10.1371/journal.pone.0073713

Costa G, Lom J, Andrade C, Barradas R (1998) First report of Ceratomyxa sparusaurati (Protozoa: Myxosporea) and the occurrence of epitheliocystis in cultured sea bream, Sparus aurata L. from Madeira. Bull Eur Assoc Fish Pathol 18:165-167

Diamant A, Lom J, Dyková I (1994) Myxidium leei n. sp., a pathogenic myxosporean of cultured sea bream Sparus aurata. Dis Aquat Org 20:137-141

Diamant A, Ucko M, Paperna I, Colorni A, Lipshitz A (2005) Kudoa iwatai (Myxosporea: Multivalvulida) in wild and cultured fish in the Red Sea: redescription and molecular phylogeny. J Parasitol 91: 1175-1189. doi:10.1645/GE-491R.1

Dyková I, Kodádková A, de Buron I, Fiala I, Roumillat WA (2013) Sinuolinea infections in the urinary system of Cynoscion species (Sciaenidae) and phylogenetic position of the type species of Sinuolinea Davis, 1917 (Myxozoa: Myxosporea). Int J Parasitol Parasites Wildl 2:10-17. doi:10.1016/j.ijppaw.2012.11.004

Eszterbauer E (2004) Genetic relationship among gill-infecting Myxobolus species (Myxosporea) of cyprinids: molecular evidence of importance of tissue-specificity. Dis Aquat Org 58:35-40. doi:10. 3354/dao058035

Eszterbauer E, Székely C (2004) Molecular phylogeny of the kidneyparasitic Sphaerospora renicola from common carp (Cyprinus carpio) and Sphaerospora sp. from goldfish (Carassius auratus auratus). Acta Vet Hung 52:469-478. doi:10.1556/AVet.52.2004.4.9

Fiala I (2006) The phylogeny of Myxosporea (Myxozoa) based on small subunit ribosomal RNA gene analysis. Int J Parasitol 36:1521-1534. doi:10.1016/j.ijpara.2006.06.016

Fiala I, Bartošová P (2010) History of myxozoan character evolution on the basis of rDNA and EF-2 data. BMC Evol Biol 10:228. doi:10. 1186/1471-2148-10-228

Fioravanti ML, Caffara M, Florio D, Gustinelli A, Marcer F (2006) A parasitological survey of european sea bass (Dicentrarchus labrax) and gilthead sea bream (Sparus aurata) cultured in Italy. Vet Res Commun 30:249-252. doi:10.1007/s11259-006-0053-5

Freeman MA, Yokoyama H, Ogawa K (2008) Description and phylogeny of Ceratomyxa anko sp. n. and Zschokkella lophii sp. n. from the Japanese anglerfish, Lophius litulon (Jordan). J Fish Dis 31:921930. doi:10.1111/j.1365-2761.2008.00965.x

Hallett SL, Diamant A (2001) Ultrastructure and small-subunit ribosomal DNA sequence of Henneguya lesteri $\mathrm{n}$. sp. (Myxosporea), a parasite of sand whiting Sillago analis (Sillaginidae) from the coast of Queensland, Australia. Dis Aquat Org 46:197-212. doi:10.3354/ dao046197

Holzer AS, Sommerville C, Wootten R (2004) Molecular relationships and phylogeny in a community of myxosporeans and actinosporeans based on their 18S rDNA sequences. Int J Parasitol 34:1099-1111. doi:10.1016/j.ijpara.2004.06.002

Jones S, Fiala I, Prosperi-Porta G, House M, Mumford S (2011) Sphaerospora elwhaiensis sp. n. (Myxosporea: Sphaerosporidae) from landlocked sockeye salmon Oncorhynchus nerka 
(Salmoniformes: Salmonidae) in Washington State, USA. Folia Parasitol 58:87-94

Kent ML, Andree KB, Bartholomew JL, El-Matbouli M, Desser SS, Devlin RH, Feist SW, Hedrick RP, Hoffmann RW, Khattra J, Hallett SL, Lester RJG, Longshaw M, Palenzeula O, Siddall ME, Xiao C (2001) Recent advances in our knowledge of the Myxozoa. J Eukaryot Microbiol 48:395-413. doi:10.1111/j.1550-7408.2001.tb00173.x

Kovalyova AA, Velev P, Vladev P (1993) New data on myxosporidians (Cnidospora: Myxosporea) fauna from commercial fishes of the Atlantic coast of Africa. In: Bukatin PA (ed) Ecology and resources of commercial fishes of the eastern Atlantic. AtlantNIRO, Kaliningrad, pp 174-194 (In Russian)

Liu Y, Whipps CM, Gu ZM, Zeng LB (2010) Myxobolus turpisrotundus (Myxosporea: Bivalvulida) spores with caudal appendages: investigating the validity of the genus Henneguya with morphological and molecular evidence. Parasitol Res 107:699-706. doi:10.1007/ s00436-010-1924-9

Lom J, Arthur JR (1989) A guideline for the preparation of species descriptions in Myxosporea. J Fish Dis 12:151-156. doi:10.1111/j. 1365-2761.1989.tb00287.x

Lom J, Dyková I (1993) Scanning electron microscopic revision of common species of the genus Chloromyxum (Myxozoa: Myxosporea) infecting European freshwater fishes. Folia Parasitol 40:161-174

Lom J, Dyková I (1995) New species of the genera Zschokkella and Ortholinea (Myxozoa) from the Southeast Asian teleost fish, Tetraodon fluviatilis. Folia Parasitol 42:161-168

Lom J, Dyková I (2006) Myxozoan genera: definition and notes on taxonomy, life-cycle terminology and pathogenic species. Folia Parasitol 53:1-36

Lom J, Noble ER (1984) Revised classification of the class Myxosporea Bütschli, 1881. Folia Parasitol 31:193-205

Lom J, Rohde K, Dyková I (1992) Studies on protozoan parasites of Australian fishes. 1. new species of the genera Coccomyxa Leger et Hesse, 1907, Ortholinea Shulman, 1962 and Kudoa Meglitsch, 1947 (Myxozoa, Myxosporea). Folia Parasitol 39: 289-306

Meglitsch PA (1970) Some coelozoic myxosporida from New Zealand fishes: family Sphaerosporidae. J Eukaryot Microbiol 17:112-115. doi:10.1111/j.1550-7408.1970.tb05168.x

Merella P, Garippa G, Salati F (2006) Parasites of cage cultured European seabass Dicentrarchus labrax and gilthead seabream Sparus aurata from Sardinia (Western Mediterranean): first results. Parasitologia 48:290

Mladineo I, Petrić M, Šegvić T, Dobričić N (2010) Scarcity of parasite assemblages in the Adriatic-reared European sea bass (Dicentrarchus labrax) and sea bream (Sparus aurata). Vet Parasitol 174:131-138. doi:10.1016/j.vetpar.2010.08.015

Molnár K, Eszterbauer E, Székely C, Dán Á, Harrach B (2002) Morphological and molecular biological studies on intramuscular Myxobolus spp. of cyprinid fish. J Fish Dis 25:643-652. doi:10. 1046/j.1365-2761.2002.00409.x

Moreira GSA, Adriano EA, Silva MRM, Ceccarelli PS, Maia AAM (2013) Morphology and 18S rDNA sequencing identifies Henneguya visibilis n. sp., a parasite of Leporinus obtusidens from
Mogi Guaçu River, Brazil. Parasitol Res 113:81-90. doi:10.1007/ s00436-013-3629-3

Moshu AJ, Trombitsky ID (2006) New parasites (Apicomplexa, Cnidospora) of some Clupeidae fishes from the Danube and Dniester basins. Acad Leo Berg, Collect Sci Artic 130:95-103

Padma Dorothy K, Kalavati C (1993) A new myxosporean parasite, Ortholinea visakhapatnamensis $\mathrm{n}$. $\mathrm{sp}$. from the mullet, Liza macrolepis from Visakhapatnam Harbour, India. Riv Parassitol 54: 461-465

Rocha S, Casal G, Matos P, Dkhil M, Azevedo C (2011) Description of Triangulamyxa psittaca sp. nov. (Myxozoa: Myxosporea), a new parasite in the urinary bladder of Colomesus psittacus (Teleostei) from the Amazon River, with emphasis on the ultrastructure of plasmodial stages. Acta Protozool 50:327-338. doi:10.4467/ 16890027AP.11.030.0067

Rocha S, Casal G, Rangel L, Severino R, Castro R, Azevedo C, Santos MJ (2013) Ultrastructural and phylogenetic description of Zschokkella auratis sp. nov. (Myxozoa), a parasite of the gilthead seabream Sparus aurata. Dis Aquat Org 107:19-30. doi:10.3354/ dao02661

Sarkar NK (1999) Ortholinea gadusiae sp. n. and Sphaeromyxa opisthopterae sp. n. (Myxozoa: Myxosporea) from the clupeid fish of the Bay of Bengal, West Bengal, India. Acta Protozool 38:145-153

Sitjà-Bobadilla A, Álvarez-Pellitero P (1993) Zschokkella mugilis n. sp. (Myxosporea: Bivalvulida) from mullets (Teleostei: Mugilidae) of Mediterranean waters: light and electron microscopic description. J Eukaryot Microbiol 40:755-764. doi:10.1111/j.1550-7408.1993. tb04471.x

Sitjà-Bobadilla A, Álvarez-Pellitero P (1995) Light and electron microscopic description of Polysporoplasma n. g. (Myxosporea: Bivalvulida), Polysporoplasma sparis n. sp. from Sparus aurata (L.) and Polysporoplasma mugilis n. sp. from Liza aurata. Eur J Protistol 31:77-89. doi:10.1016/S0932-4739(11)80360-3

Sitjà-Bobadilla A, Álvarez-Pellitero P (2001) Leptotheca sparidarum $\mathrm{n}$. sp. (Myxosporea: Bivalvulida), a parasite from cultured common dentex (Dentex dentex L.) and gilthead sea bream (Sparus aurata L.) (Teleostei: Sparidae). J Eukaryot Microbiol 48:627-639. doi:10. 1111/j.1550-7408.2001.tb00202.x

Sitjà-Bobadilla A, Franco-Sierra A, Álvarez-Pellitero P (1992) Sphaerospora (Myxosporea: Bivalvulida) infection in cultured gilt head sea bream, Sparus aurata L.: a preliminary report. J Fish Dis 15:339-343. doi:10.1111/j.1365-2761.1992.tb00672.x

Sitjà-Bobadilla A, Palenzuela O, Alvarez-Pellitero P (1995) Ceratomyxa sparusaurati $\mathrm{n}$. sp. (Myxosporea: Bivalvulida), a new parasite from cultured gilthead seabream (Sparus aurata L.) (Teleostei: Sparidae): light and electron microscopic description. J Eukaryot Microbiol 42: 529-539. doi:10.1111/j.1550-7408.1995.tb05901.x

Su X, White RWG (1994) New myxosporeans (Myxozoa: Myxosporea) from marine fishes of Tasmania, Australia. Acta Protozool 33:251-259

Tamura K, Peterson D, Peterson N, Stecher G, Nei M, Kumar S (2011) MEGA5: Molecular Evolutionary Genetics Analysis using maximum likelihood, evolutionary distance, and maximum parsimony methods. Mol Biol Evol 28:2731-2739. doi:10.1093/molbev/ msr121 